Original research article

\title{
An evaluation of the quality of life and sexual status functions of females with urinary incontinence
}

\author{
Funda Çetinkaya ${ }^{1}{ }^{*}$, Neziha Karabulut ${ }^{2}$, Sevinç Köse Tuncer ${ }^{3}$ \\ ${ }^{1}$ Aksaray University, Faculty of Health Sciences, Department of Surgical Nursing, Aksaray, Turkey \\ ${ }^{2}$ Atatürk University, Faculty of Nursing, Department of Surgical Nursing, Erzurum, Turkey \\ ${ }^{3}$ Erzincan University, Faculty of Health Sciences, Department of Obstetrics and Gynaecology Nursing, Erzincan, Turkey
}

\section{Abstract}

Objectives: This research was carried out as a descriptive study in order to determine the quality of life and sexual status functions of women with urinary incontinence (UI) in Turkey.

Materials and methods: The study was conducted with 92 women who were admitted with a urinary incontinence complaint to the urology policlinic of a state hospital. The data was collected by the researcher using the Introductory Information Form, Wagner's Quality of Life Scale (QOL) and Female Sexual Function Index (FSFI). Analysis of the data was performed using percentage, mean, Kruskal-Wallis and MW-U test.

Results: The mean score of women on Wagner's QOL scale was $41.69 \pm 22.97$, and the Female Sexual Function Index total score average was $50.26 \pm 11.37$. In this study of women, a significant statistical difference was found between Wagner's QOL scale point average and the age, education level, and place of residence $(p<0.05)$. The women's mean score on the FSFI scale was 50.26 \pm 11.37 .

Conclusions: The results of the study show that urinary incontinence negatively affects the quality of life and sexual function of females.
\end{abstract}

Keywords: Life quality; Sexuality; Urinary incontinence; Women

\section{Introduction}

Urinary incontinence (UI) is defined by the International Continence Society (ICS) as "the complaint of any involuntary leakage of urine whatever the amount", or as "urine leakage seen as urethral or extra urethral during examination" (Alexander et al., 2015; Amaral et al., 2015).

Urinary incontinence has affected more than 200 million people around the world, and the problem is $10-60 \%$ more prevalent among women (Akkoca et al., 2014). In our country, it is stated that there is a urinary incontinence problem in 25 out of every 100 females (Eskiyurt and Karan, 2000).

Epidemiologic studies have shown that urinary incontinence is associated with many risk factors, including age, pregnancy, vaginal childbirth, obesity, illnesses that involve chronic increase of abdominal pressure, menopause, hysterectomy, constipation, hypooestrogenism, trauma, genetic factors, use of tobacco and previous surgeries (Amaral et al., 2015, Dolan and Hilton, 2010; Menezes et al., 2010). Although urinary incontinence is not a life-threatening disease it has a negative impact on women's physical and psychological well-being, socioeconomic status, and hygiene (Cerruto et al., 2013; Kocaöz and Eroğlu, 2009). The literature states that females with urinary incontinence voluntarily isolate themselves from social life, avoid daily relationships, restrict their physical activities and even reduce the amount of daily fluid intake. The quality of life of females is negatively affected due to these problems (Aslan, 2002; Dilek, 2008). Studies have shown that in women with UI, not only does the quality of life deteriorate, but also sexual activity - one of the most important criteria of quality of life (Pauls et al., 2007; Rogers et al., 2006; Yilmaz et al., 2014). Difficulty during sexual intercourse arises, such as the fear of urine loss or the need to interrupt sexual intercourse to urinate (Lacombe et al., 2015).

This leads to a further deterioration of the quality of life and mental health. Despite the discomfort caused by UI, some individuals with this disorder do not seek medical care because they see it as a normal physiological condition or due to embarrassment (Amaral et al., 2015; Yllmaz et al., 2014). But for females with UI a holistic approach to medical care and to improve quality of life and resolve sexual function problems is important.

Epidemiological studies conducted on UI show that as well as being a health problem, urinary incontinence is a social problem at the same time - it negatively affects the social lives of the individuals, their self-esteem, emotional conditions, quality of life and sexual function (Mishra et al., 2015; Thiagamoorthy et al., 2015). Urinary incontinence affects females of various age groups around the world (Lacombe et al., 2015).

\footnotetext{
* Author for correspondence: Funda Çetinkaya, Aksaray University, Faculty of Health Sciences, Department of Surgical Nursing, Adana Yolu Üzeri 7, km Aksaray, Turkey; e-mail: fundacetinkaya@aksaray.edu.tr http://doi.org/10.32725/kont.2019.006 
Urinary incontinence negatively affects the quality of life of about $15-30 \%$ of females in the general population, $20 \%$ of middle-aged females and $45 \%$ of older females (Stach-Lempinen et al., 2004). The literature has determined that individuals with urinary incontinence have seen a decrease in their confidence due to their discomfort; they see themselves as dependent, they feel different from other people in society, they experience social isolation, they restrict their social and physical experiences, their social relations, and their sexual life (Pauls et al., 2007; Rogers et al., 2006). Marital relationships are also harmed (Koçak et al., 2005; Papanicolaou et al., 2005; Parazzini et al., 2003; Oh et al., 2008). This leads to a further deterioration of the quality of life and mental health (Peyrat et al., 2002). Nurses who spend the most time with patients and observe them in the most accurate manner have an important role in the determination of the problems related to sexual life and quality of life with the observations and evaluations they make.

The aim of this study was to assess the quality of life and sexual status functions of females with UI.

\section{Materials and methods}

\section{Study participants}

This research was carried out as a descriptive study in order to determine the quality of life and sexual status functions of women with UI in Turkey.

This cross-sectional study was conducted between July 2015 and January 2016 in the urology policlinic of the state hospital in Turkey. A random sample of female patients $(n=$ 92) who were admitted to the urology policlinic with a urinary incontinence complaint were included.

\section{Data collection}

The data was collected by the researcher using the Introductory Information Form, Wagner's Quality of Life Scale (QOL) and Female Sexual Function Index (FSFI).

Introductory information form: This consists of a total of 12 questions including demographic items (i.e. age, marital status, education level,) and questions about incontinence (i.e incontinence frequency, how much urine is leaking).

Wagner's Quality of Life (QOL) scale: Wagner's QOL scale was developed by Wagner et al. (1996). The Turkish version of the scale was used by Karan et al. (2000). This scale poses 28 questions related to UI. Participants are asked to answer each question by selecting one of the following alternatives, 'no/mild/moderate/severe'. The answers are scored as $0 / 1 / 2 / 3$ respectively. According to this, a score total of 0 means the absence of incontinence and psychological problems; 1-28 means a mild degree disorder, 29-56 means a moderate disorder; and $57-84$ is taken to mean a severe disorder.

Female Sexual Function Index (FSFI): The FSFI was developed by Rosen et al. (2000). The Turkish version of the scale was used by Aygin and Aslan (2005). This scale is a 19-item, multidimensional, self-report measure comprised of a full scale and six subscales (i.e., desire, arousal, lubrication, orgasm, satisfaction and pain) to measure sexual function. The six domains belonging to the female sexual function index (FSFI) questionnaire calculator are defined as: desire (item 1, 2), arousal (item 3, 4, 5, 6), lubrication (item 7, 8, 9, 10), orgasm (item 11,12, 13), satisfaction (item 14, 15, 16), and pain (item 17, 18, 19). The lowest score was calculated as 2 and the highest score as 36 . The total FSFI score under 26.55 was accepted as sexual dysfunction (Aygin and Aslan, 2005).
The measure was designed for use in clinical trials. Thus, the desire, arousal, lubrication, orgasm, and pain subscales correspond to the five domains considered relevant for the sexual dysfunction disorders (hypoactive sexual desire disorder, sexual arousal disorder, sexual pain disorders, and orgasmic disorder).

Data were collected through face-to face interviews by researchers in patient interview rooms at hospital. During the interviews, questions were read, and the appropriate choices were marked on the questionnaire according to the urinary incontinent woman's answer. Interviews took approximately 25 minutes.

\section{Statistical analysis}

The Statistical Package for Social Sciences (SPSS) for Windows, version 16.0, was used for data entry and analysis. Women's demographic variables and information on incontinence were evaluated using the percentage distribution and mean. Kruskal-Wallis and MW- $U$ test were used to make a comparison of scale point averages and women' demographic variables.

\section{Limitations of the study}

The limitations of the study are due to females not responding to the question on sexual function and a limited sample reach.

\section{Results}

A total of 92 women participated. Of the women included in the study, $31.5 \%$ were between 40 and 49 years, $58.7 \%$ were primary school graduates, $80.4 \%$ lived in urban areas, $60.9 \%$ were housewives, and $31.5 \%$ had an average level of income (Table 1). When the complaints related to urinary incontinence of the women participating in the study were examined; $45.7 \%$ of women experience urinary leakage one or more times a week, $53.3 \%$ in a small amount, $40.7 \%$ experience urinary leakage without going to the toilet, and $29.4 \%$ whilst coughing or sneezing (Table 2). It has been determined that the problem

\begin{tabular}{|c|c|c|}
\hline Socio-demographic characteristics & Number & $\%$ \\
\hline \multicolumn{3}{|l|}{ Age } \\
\hline $20-29$ & 12 & 13.0 \\
\hline $30-39$ & 23 & 25.0 \\
\hline $40-49$ & 19 & 31.5 \\
\hline $50-59$ & 16 & 17.4 \\
\hline 60 years and over & 12 & 13.0 \\
\hline \multicolumn{3}{|l|}{ Level of education } \\
\hline elementary education & 54 & 58.7 \\
\hline high school & 27 & 29.3 \\
\hline college/faculty & 11 & 12.0 \\
\hline \multicolumn{3}{|l|}{ Place of residence } \\
\hline rural & 18 & 19.6 \\
\hline urban & 74 & 80.4 \\
\hline \multicolumn{3}{|l|}{ Job } \\
\hline housewife & 56 & 60.9 \\
\hline officer/worker & 23 & 25.0 \\
\hline retired & 13 & 14.1 \\
\hline \multicolumn{3}{|l|}{ Income status } \\
\hline income is less than expenses & 58 & 63.1 \\
\hline income is equivalent to expenses & 29 & 31.5 \\
\hline income is more than expenses & 5 & 5.4 \\
\hline
\end{tabular}


of urinary incontinence affects the daily lives of women by an average of $4.71 \pm 2.75$. The mean score of women on Wagner's QOL scale was $41.69 \pm 22.97$ and the Female Sexual Function Index total score average was $50.26 \pm 11.37$ (Table 3 ).

\section{Table 2. Information about incontinence of woman}

\begin{tabular}{lrr} 
Complaints about urinary incontinence & Number & $\%$ \\
\hline How often do you experience urinary leakage? & & \\
never & \multicolumn{1}{c}{ \% } & 5.4 \\
one or more times a week & 42 & 45.7 \\
two or three times a week & 15 & 16.3 \\
once a day & 4 & 4.3 \\
several times a day & 13 & 14.1 \\
always & 13 & 14.1 \\
How much urine are you leaking? & & \\
none & 4 & 4.3 \\
a small amount & 49 & 53.3 \\
a medium amount & 24 & 26.1 \\
a lot & 15 & 16.3 \\
In which situations are you experiencing urinary & & \\
leakage? & & \\
never & 0 & 0.0 \\
without a toilet & 37 & 40.2 \\
when coughing or sneezing & 27 & 29.4 \\
when asleep & 4 & 4.3 \\
while on the move or while doing sports & 17 & 18.5 \\
when getting dressed & 15 & 16.3 \\
without a clear cause & 12 & 13.0 \\
always & 0 & 0.0 \\
\hline * More than one opinion marked. & & \\
\hline
\end{tabular}

Table 3. Women's quality of life, sexual desire index sub-dimension and total average score

\begin{tabular}{lc} 
Scales & Mean \pm SD (min-max) \\
\hline $\begin{array}{l}\text { The average score of the quality of } \\
\text { life scale }\end{array}$ & $41.69 \pm 22.97$ (min: 0 -max: 80$)$ \\
The average score of Female Sexual & \\
Function Index and Sub-dimension & \\
$\quad$ desire & $7.35 \pm 1.86$ (min: 2 -max: 10$)$ \\
arousal & $6.15 \pm 3.44(\min : 0-\max : 20)$ \\
lubrication & $11.63 \pm 3.93(\min : 0-\max : 20)$ \\
orgasm & $7.96 \pm 3.59(\min : 0-\max : 15)$ \\
satisfaction & $8.16 \pm 3.65$ (min: $2-\max : 15)$ \\
pain & $8.98 \pm 4.36$ (min: $0-\max : 15)$ \\
the average score of female sexual & \\
function index & $50.26 \pm 11.37$ (min: 4 -max: 95$)$ \\
\hline
\end{tabular}

In this study of women, a statistically significant difference was found between Wagner's QOL scale point average and the age, education level, place of residence, incontinence frequency and amount of incontinence $(p<0.05)$. Females who experience urinary incontinence had a FSFI scale mean total score of $50.26 \pm 11.37$. There was a statistically significant difference between place of residence, occupation groups and incontinence frequency and FSFI score averages (Table 4). These results show that as the incidence of urinary incontinence increases, the quality of life decreases and sexual life is adversely affected. As the amount of leaking urine increased, the quality of life of the women decreased significantly. In addition, in this study the amount of leaking urine does not affect the women's sexual function.

\section{Discussion}

The results of the study show that urinary incontinence negatively affects the quality of life and sexual function of females. The mean age of the females included in the study was 48.01 \pm 13.41 (range $27-79$ years) (Table 1 ). Although it is prevalent among the elderly, the incidence of urinary incontinence which has significant effects on the physical, psychological and socioeconomic aspects of the life of people can be seen not only in the elderly population but also in young and middle-aged populations (Koçak et al., 2005). Diseases common to older females can lead to urinary incontinence disturbing the continence mechanism (Dikencik, 2002). The literature stated that the age range of the urine incontinence studies was between 20-75. The results of this study are similar to those of previous studies (Amaral et al., 2015; Güdücü and Keser Özcan, 2016).

When the complaints related to urinary incontinence were examined, $45.7 \%$ of women reported having urinary leakage once or rarely per week (Table 2). The study, conducted by Özerdogan and Kizılkaya (2003), found that out of 161 females with urinary incontinence, $36.1 \%$ experienced it rarely, and $51.6 \%$ frequently. In this study it was determined that $40.7 \%$ of the females were unable to reach the toilet, and 29.4\% experienced urinary leakage when coughing and sneezing (Table 1). Topuz (2011) also found that females mostly had urinary incontinence when coughing and sneezing. Coughing and sneezing lead to increased intraabdominal pressure, which leads to urinary incontinence. Therefore, in this study, urinary incontinence resulting from coughing and sneezing was an expected result.

In this study, the mean score of women on Wagner's QOL scale was $41.69 \pm 22.97$ and the women were found to have moderate impairment (Table 3 ). $79 \%$ of females with UI had a moderate to severe degree of negative impact on their quality of life (Ghafouri et al., 2014). The literature reports that urinary incontinence negatively affects the quality of life in females (Amaral et al., 2015; Coyne et al., 2012; Lasserre et al., 2009; Yilmaz et al., 2014). The results of this study are similar to those of previous studies. The study found that females in the 20-29 age group had mild urinary incontinence and a mild degree of impairment. There was severe urinary incontinence and severe disability in females over 60 years of age. This result shows that as the age increases, the risk of urinary incontinence increases. Bladder function and morphology change with age, and the capacity of the bladder to delay urination also decreases (Topuz, 2011; Tsai and Liu, 2009). In addition, the deterioration in the urethral muscle structure and the decrease in the number of striated muscle fibers in the front wall of the urethra along with advancing age might increase the frequency of UI (Akyolet al., 2007). Therefore, it can be considered that the frequency of urinary incontinence increases with age. This study found that the incidence of urinary incontinence was higher in the low education group (Table 4). Parazzini et al. (2003) reported that the possibility of urinary incontinence increases in individuals with low education. Koçak et al. (2005) found that the level of education was lower in the group with urinary incontinence. However, Kocaöz and Eroğlu (2009), Oh et al. (2008) stated that there was no association between education level and incontinence. In the present study, females living in small towns and housewives were found to have more urinary incontinence problems (Table 4). Women with a low level of education and who live in small towns have very and frequent births. This may be associated with the impairment in the pelvic muscle nerves during birth, the development of 
Table 4 - The relationship between the total average score of women's quality of life and sexual desire scale and variables $(n=92)$

\begin{tabular}{|c|c|c|c|}
\hline Variables & $n$ & QOL scale average score & FSFI average score \\
\hline \multicolumn{4}{|l|}{ Age } \\
\hline $20-29$ & 12 & $24.91 \pm 18.94$ & $47.16 \pm 10.97$ \\
\hline $30-39$ & 23 & $34.34 \pm 22.08$ & $50.56 \pm 7.74$ \\
\hline $40-49$ & 29 & $38.96 \pm 17.26$ & $52.34 \pm 6.96$ \\
\hline $50-59$ & 16 & $48.43 \pm 24.67$ & $47.50 \pm 17.88$ \\
\hline \multirow[t]{2}{*}{60 years and over } & 12 & $70.16 \pm 7.28$ & $51.41 \pm 15.35$ \\
\hline & & $\begin{array}{c}\mathrm{KW}=30.194 \\
\boldsymbol{p}=\mathbf{0 . 0 0 0}\end{array}$ & $\begin{array}{l}\mathrm{KW}=2.92 \\
\boldsymbol{p}=\mathbf{0 . 5 7 0}\end{array}$ \\
\hline \multicolumn{4}{|l|}{ Education } \\
\hline elementary education & 54 & $46.81 \pm 23.64$ & $48.27 \pm 13.61$ \\
\hline high school & 27 & $34.44 \pm 18.86$ & $52.81 \pm 5.58$ \\
\hline \multirow[t]{2}{*}{ college/faculty } & 11 & $34.36 \pm 23.93$ & $53.72 \pm 7.82$ \\
\hline & & $\begin{array}{c}\mathrm{KW}=7.233 \\
\boldsymbol{p}=\mathbf{0 . 0 2 7}\end{array}$ & $\begin{array}{l}\mathrm{KW}=1.43 \\
\boldsymbol{p}=\mathbf{0 . 4 8 0}\end{array}$ \\
\hline \multicolumn{4}{|l|}{ Place of residence } \\
\hline rural & 18 & $60.94 \pm 19.15$ & $41.72 \pm 16.26$ \\
\hline \multirow[t]{2}{*}{ urban } & 74 & $21.42 \pm 21.42$ & $52.33 \pm 8.79$ \\
\hline & & $\begin{array}{c}M W-U=257.5 \\
\boldsymbol{p}=\mathbf{0 . 0 0 0}\end{array}$ & $\begin{array}{c}\mathrm{MW}-U=401.5 \\
\boldsymbol{p}=\mathbf{0 . 0 0 0}\end{array}$ \\
\hline \multicolumn{4}{|l|}{ Job } \\
\hline housewife & 56 & $46.46 \pm 22.96$ & $48.35 \pm 12.77$ \\
\hline officer/ worker & 23 & $27.69 \pm 20.63$ & $50.65 \pm 7.74$ \\
\hline \multirow[t]{3}{*}{ retired } & 13 & $45.92 \pm 17.44$ & $57.76 \pm 6.71$ \\
\hline & & $\mathrm{KW}=11.175$ & $\mathrm{KW}=8.92$ \\
\hline & & $p=0.004$ & $p=0.011$ \\
\hline \multicolumn{4}{|c|}{ How often do you experience urinary leakage? } \\
\hline never & 5 & $10.20 \pm 9.65$ & $42.80 \pm 13.21$ \\
\hline one or more times a week & 42 & $30.83 \pm 1.95$ & $51.45 \pm 8.55$ \\
\hline two or three times a week & 15 & $49.13 \pm 1.92$ & $50.60 \pm 12.55$ \\
\hline once a day & 4 & $37.25 \pm 2.80$ & $59.0 \pm 8.98$ \\
\hline several times a day & 13 & $57.69 \pm 1.36$ & $55.61 \pm 9.14$ \\
\hline \multirow[t]{3}{*}{ always } & 13 & $65.69 \pm 1.72$ & $40.84 \pm 14.29$ \\
\hline & & $\mathrm{KW}=39.928$ & $\mathrm{KW}=16.114$ \\
\hline & & $p=0.000$ & $p=0.007$ \\
\hline \multicolumn{4}{|c|}{ How much urine are you leaking? } \\
\hline none & 4 & $8.5 \pm 9.81$ & $52.0 \pm 8.08$ \\
\hline a small amount & 49 & $31.53 \pm 1.93$ & $51.53 \pm 9.25$ \\
\hline a medium amount & 24 & $54.16 \pm 1.55$ & $51.41 \pm 11.96$ \\
\hline \multirow[t]{2}{*}{ a lot } & 15 & $63.80 \pm 1.62$ & $43.80 \pm 15.64$ \\
\hline & & $\begin{array}{c}\mathrm{KW}=38.832 \\
\boldsymbol{p}=\mathbf{0 . 0 0 0}\end{array}$ & $\begin{array}{c}\mathrm{KW}=2.286 \\
\boldsymbol{p}=\mathbf{0 . 5 1 5}\end{array}$ \\
\hline
\end{tabular}

atrophy in muscles, and the development of prolapsed over time. In addition, we can assume that the information about the kegel exercises for females with a low education level is inadequate; the prevention of incontinence and these exercises (which are useful in the treatment of mild incontinence) are not done effectively. For this reason, women with a low level of education may be considered to experience high incontinence. In this study, females who experience urinary incontinence had an FSFI scale mean total score $50.26 \pm 11.37$ (Table 2). This result shows that their sexual functions are negatively affected. Sexual functions are an important part of the quality of life. The female who has urinary leakageloses self-esteem, is embarrassed, prevented from having sexual intercourse, and ultimately negatively affected in terms of sexual satisfaction (Akham, 2009). Döndar (2006) reported that females with urinary incontinence who applied to the urogynecology polyclinic had a $91.3 \%$ prevalence of sexual dysfunction. Rogers et al. (2006), found that females with incontinence had less frequent sexual activity and their sexual functions were negatively affected by incontinence. Lim et al. (2016) found that stress urinary incontinence negatively affects sexual function in females. Felippe et al. (2017) reported that females with UI showed less sexual desire, sexual comfort, and sexual satisfaction. Sexuality and sexual function is a condition that has been seen as a taboo for many years and cannot be talked about, including by health professionals (Aygin and Aslan, 2005). We can say that females may have problems with sexual functioning because it is not possible to talk about the incontinence and obtain treatment. 


\section{Conclusions}

The present results indicate that UI has a negative impact on the quality of life of females and sexual functions. As a result of the study, it is recommended to evaluate the sexual life, quality of life and the influencing factors with a larger sample group.

\section{Ethical approval}

The study was approved by the ethics committee of Aksaray University. Written consent was obtained from the director of the institution. All participants were informed of the purpose and design of the study, and oral consent was obtained from those who agreed to enrol in it. Participation in the study was voluntary.

\section{Conflict of interests}

The authors declare that they have no conflict of interest regarding this paper.

\section{Hodnocení kvality života a pohlavních funkcí žen s inkontinencí moči}

\section{Souhrn}

Cíl: Tento výzkum byl proveden jako popisná studie určující kvalitu života a pohlavní funkce žen s močovou inkontinencí (MI) v Turecku.

Metodika: Studie byla provedena u 92 žen, které byly přijaty kvůli stížnostem na močovou inkontinenci na urologické ambulanci státní nemocnice. Data byla shromážděna výzkumným pracovníkem pomocí Úvodního informačního formuláře, Wagnerovy škály skóre kvality života (QOL) a indexu sexuální funkce žen (FSFI). Analýza dat byla provedena procentuálně, pomocí průměru, Kruskal-Wallisova testu a MW-U testu.

Výsledky: Průměrné skóre žen na Wagnerově QOL stupnici bylo 41,69 $\pm 22,97$ a celkový průměr indexu ženské sexuální funkce byl $50,26 \pm 11,37$. V této studii o ženách byly zjištěny významné statistické rozdíly mezi hodnotou Wagnerova průměru QOL a věkem, úrovní vzdělání a místem pobytu $(p<0,05)$. Průměrné skóre žen na stupnici FSFI bylo 50,26 $\pm 11,37$.

Závěr: Výsledky studie prokazují, že močová inkontinence negativně ovlivňuje kvalitu života a sexuální funkci žen.

Klíčová slova: kvalita života; močová inkontinence; ženy; sexualita

\section{References}

1. Akhan SE (2009). The effects of pelvic floor dysfunction on female sexuality. Turkiye Klinikleri J Gynecol Obst-Special Topics 2(2): 77-85.

2. Akkoca AN, Özdemir ZT, Kurt RK, Özler S, Arıca SG, Özer C (2014). The questioning of family history and enuresis nocturna story in women with urinary incontinence. Medical Journal of Mustafa Kemal University 20(5).

3. Akyol A, Mutlu S, Ark H, Çelebi İ (2007). Relationshıp between dispersions of urodynamics diagnosis and type of delivery, birth weight and menopause. Turkiye Klinikleri J Gynecol Obst 17(4): 276-282.

4. Alexander L, Shakespeare K, Barradell V, Orme S (2015). Management of urinary incontinence in frail elderly women. Obstet Gynaecol Reprod Med 25(3): 75-82. DOI: 10.1016/j. ogrm.2015.01.002.

5. Amaral MO, Coutinho EC, Nelas PA, Chaves CM, Duarte JC (2015). Risk factors associated with urinary incontinence in Portugal and the quality of life of affected women. I J Gynecol Obstet 131(1): 82-86. DOI: /10.1016/j.ijgo.2015.03.041.

6. Aslan E (2002). Effect of urinary incontinence on quality of life. In: Beji NK (Ed.). Urinary incontinence and nursing approach in women. Istanbul: Emek Printing, pp. 51-60.

7. Aygin D, Aslan F (2005). What are we doing in sexual dysfunctions? What should we do? Androloji Bülteni 22: 264-267.

8. Cerruto MA, D’Elia C, Aloisi A, Fabrello M, Artibani W (2013). Prevalence, incidence and obstetric factors' impact on female urinary incontinence in Europe: a systematic review. Urol Int 90(1): 1-9. DOI: 10.1159/000339929.

9. Coyne KS, Kvasz M, Ireland AM, Milsom I, Kopp ZS, Chapple CR (2012). Urinary incontinence and its relationship to mental health and health-related quality of life in men and women in Sweden, the United Kingdom, and the United States. Eur Urol 61(1): 88-95. DOI: 10.1016/j.eururo.2011.07.049.
10. Dikencik BK (2002). Epidemiology and risk factors of urinary incontinence. In: Kizilkaya Beji N (Ed.). Urinary incontinence and nursing approach in women. Istanbul: Istanbul University, pp. 29-49.

11. Dilek KU (2008). Urinary incontinence and pelvic organ prolapse anamnesis and physical examination. In: Güner $\mathrm{H}$ (Ed.). Urogynecology and pelvic reconstructive surgery. Ankara: Guneș Medicine Bookstores, pp. 63-68.

12. Dolan LM, Hilton P (2010). Obstetric risk factors and pelvic floor dysfunction 20 years after first delivery. Int Urogynecol J 21(5): 535-544. DOI: 10.1007/s00192-009-1074-8.

13. Döndar Ç (2006). Impact of urinary incontinence on female sexual functions and quality of life. Graduate thesis. Marmara University Health Sciences Institute, p. 137.

14. Eskiyurt N, Karan A (2000). Urinary incontinence physical therapy and rehabilitation. In: Güner H (Ed.). Urogynechology, Ankara, Turkey: Atlas Bookshop, pp. 135-155.

15. Felippe MR, Zambon JP, Girotti ME, Burti JS, Hacad CR, Cadamuro L, Almeida F (2017). What is the real impact of urinary incontinence on female sexual dysfunction? A case control study. Sex Med 5(1): e54-e60. DOI: 10.1016/j. esxm.2016.09.001.

16. Ghafouri A, Alnaimi AR, Alhothi HM, Alroubi I, Alrayashi M, Molhim, NA, Shokeir AA (2014). Urinary incontinence in Qatar: A study of the prevalence, risk factors and impact on quality of life. Arab J Urol 12(4): 269-274. DOI: 10.1016/j. aju.2014.08.002.

17. Güdücü N, Keser Özcan N (2016). Evaluation of sexual functions in women with urinary incontinence. JAREN 2(1): 16-23. DOI: 10.5222/jaren.2016.016.

18. Güner $\mathrm{H}$ (Ed.). Urogynecology and pelvic reconstructive surgery urogynecology. Ankara: Atlas Bookshop, pp. 135-155.

19. Karan A, Aksaç B, Akyıldız H, Işıkoğlu M, Yalçın O, Eskiyurt N (2000). Quality of life and its relation with objective assessment parameters in urinary incontinent patients. Turk J Geriatri Dergisi 3: 102-106.

20. Koçak I, Okyay P, Dündar M, Erol H, Beser E (2005). Female Urinary Incontinence in the West of Turkey: Prevalence, Risk 
Factors and Impact on Quality of Life. Eur Urol 48: 634-641. DOI: 10.1016/j.eururo.2005.04.017.

21. Kocaöz S, Eroğlu K (2009). Conservative treatment methods of stress urinary incontinence during pregnancy and after vaginal delivery and roles of nurse. Turkiye Klinikleri J Nurs Sci 1(2): 94-102.

22. Lacombe AC, Riccobene VM, Nogueira LA (2015). Effectiveness of a program of therapeutic exercises on the quality of life and lumbar disability in women with Stress Urinary Incontinence. J Bodyw Mov Ther 19: 82-88. DOI: 10.1016/j. jbmt.2014.04.002.

23. Lasserre A, Pelat C, Guéroult V, Hanslik T, Chartier-Kastler E, Blanchon T, et al. (2009). Urinary incontinence in French women: prevalence, risk factors, and impact on quality of life. Eur Urol 56(1):177-183. DOI: 10.1016/j.eururo.2009.04.006.

24. Lim R, Liong ML, Leong WS, Khan NA, Yuen KH (2016). Effect of stress urinary incontinence on the sexual function of couples and the quality of life of patients. J Urol 196(1): 153-158. DOI: 10.1016/j.juro.2016.01.090.

25. Menezes M, Pereira M, Hextall A (2010). Predictors of female urinary incontinence at midlife and beyond. Maturitas 65(2): 167-171. DOI: 10.1016/j.maturitas.2009.10.004

26. Mishra GD, Barker MS, Herber Gast GC, Hillard T (2015). Depression and the incidence of urinary incontinence symptoms among young women: Results from a prospective cohort study. Maturitas 81(4): 456-461. DOI: 10.1016/j. maturitas.2015.05.006.

27. Oh SJ, Ku JH, Choo MS, Yun JM, Kim DY, Park WH (2008). Health-related quality of life and sexual function in women with stress urinary incontinence and overactive bladder. Int J Urol 15(1): 62-67. DOI: 10.1111/j.1442-2042.2007.01905.x.

28. Özerdoğan N, Kizılkaya NB (2003). Prevalence, risk factors, and quality of life of urinary incontinence in women aged 20 and over in Eskisehir, Bilecik, Afyon and Kütahya. Nurs J 13: 37-50.

29. Papanicolaou S, Hunskaar S, Lose G, Sykes D (2005). Assessment of bothersomeness and impact on quality of life of urinary incontinence in women in France, Germany, Spain and the UK. BJU Int 96(6): 831-838. DOI: 10.1111/j.1464410X.2005.05722.x.

30. Parazzini F, Chiaffarino F, Lavezzari M, Giambanco V, VIVA Study Group (2003). Risk factors for stress urge or mixed urinary incontinence in Italy. BJOG 110: 927-933. DOI: $10.1111 /$ j.1471-0528.2003.02343.x.
31. Pauls RN, Silva WA, Rooney CM, Siddighi S, Kleeman SD, Dryfhout V, Karram MM (2007). Sexual function after vaginal surgery for pelvic organ prolapse and urinary incontinence. Am J Obstet Gynecol 197(6): 622.e1-e7. DOI: 10.1016/j. ajog.2007.08.014

32. Peyrat O, Haillot F, Bruyere JM, Bertrand P, Lanson Y (2002). Prevalence and risk factors of urinary incontinence in young and middle-aged women. BJU Int 89(1): 61-66. DOI: 10.1046/j.1464-410X.2002.02546.x.

33. Rogers RG, Kammerer-Doak D, Darrow A, Murray K, Qualls C, Olsen A, Barber M (2006). Does sexual function change after surgery for stress urinary incontinence and/or pelvic organ prolapse? A Multicenter Prospective Study. Am J Obstet Gynecol 195(5): e1-e4. DOI: 10.1016/j.ajog.2006.09.021.

34. Rosen R, Brown C, Heiman J, Leiblum S, Meston C, Shabssigh R, et al. (2000). The Female Sexual Function Index (FSFI): a multidimensional self-report instrument for the assessment of female sexual function. J Sex Marital Ther 26(2): 191-208. DOI: 10.1080/009262300278597.

35. Stach-Lempinen B, Kirkinen P, Laippala P, Metsonoja R, Kujansuu E (2004). Do objective urodynamic or clinical findings determine impact of urinary incontinence or its treatment on quality of life? Urology 63(1): 67-72. DOI: 10.1016/j. urology.2003.07.022.

36. Thiagamoorthy G, Srikrishna S, Cardozo L (2015). Sexual function after urinary incontinence surgery. Maturitas 81 : 243-247. DOI: 10.1016/j.maturitas.2015.03.002.

37. Topuz Ş (2011). Effects of kegel exercıses applied to urınary incontinence on woman sexual satısfaction. PhD thesis. Erciyes University, Institute of Health Sciences, Birth-Women's Health and Nursing.

38. Tsai YC, Liu CH (2009). Urinary incontinence among Taiwanese women: An outpatient study of prevalence, comorbidity, risk factors, and quality of life. Int Urol Nephrol 41(4): 795-803. DOI: $10.1007 /$ s11255-009-9523-3.

39. Wagner TH, Patrick DL, Bavendam TG, Martin ML, Buesching DP (1996). Quality if life of persons with urinary incontinance: development of a new measure. Urology 47(1): 67-72. DOI: 10.1016/S0090-4295(99)80384-7.

40. Yllmaz E, Muslu A, Özcan E (2014). Quality of life at women with urinary incontinence. Erciyes University Medical Science Journal 2(2). 